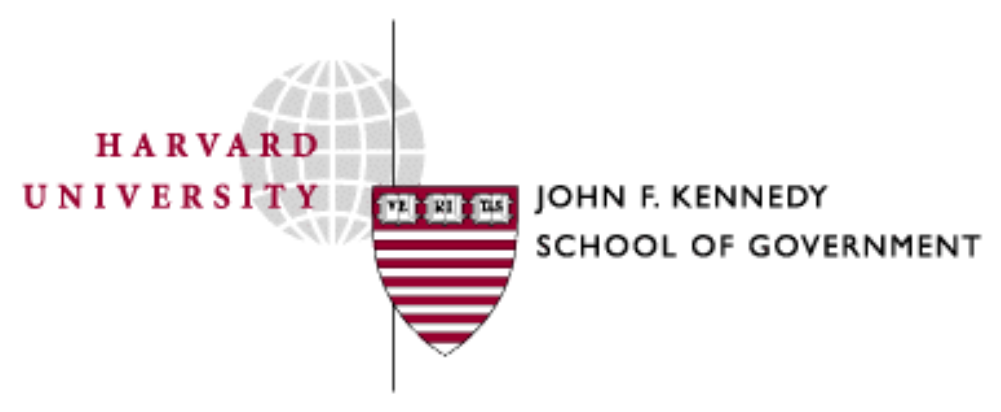

Faculty Research Working Papers Series

\title{
Real Convergence and Euro Adoption in Central and Eastern Europe: Trade and Business Cycle Correlations as Endogenous Criteria for Joining EMU
}

Jeffrey Frankel

August 2004

RWP04-039 belongs to the author(s). Papers may be downloaded for personal use only. 
January 19; revised February 5, 2004

\title{
"Real Convergence and Euro Adoption in Central and Eastern Europe: Trade and Business Cycle Correlations as Endogenous Criteria for Joining EMU"
}

\author{
Prof. Jeffrey Frankel \\ Harvard University
}

\begin{abstract}
Paper for Conference on Euro Adoption in the Accession Countries Opportunities and Challenges, Czech National Bank, Prague, Feb. 2-3, 2004. Forthcoming, International Monetary Fund, edited by Susan Schadler.
\end{abstract}

\begin{abstract}
Summary
Optimum currency area theory says that trade patterns and cyclical correlations are important criteria for whether a country should join a monetary area such as EMU. But these criteria are endogenous. Recent econometric estimates suggest that currency unions have far greater effects on trade patterns than previously believed. Since currency unions are good for trade, and trade is good for growth, that is one major argument in favor of adopting the euro. There are the usual countervailing arguments for retaining monetary independence, particularly the famous asymmetric shocks. But the pattern of shocks is also endogenous. For the countries of Central and Eastern Europe joining the EU in 2004, one risk-averse argument for joining later, but not necessarily yet, is that trade with euroland can be expected to continue increasing. Econometric estimates suggest that the growing trade links will in turn lead to growing cyclical correlation, that is, to cyclical convergence. The implication is that the new EU members may better qualify for the optimum currency area criteria in the future, even in just five years, than they do as of today. Another kind of convergence, income convergence, is also relevant, but will take too long to wait for.
\end{abstract}

The author would like to thank Dora Douglass for research assistance, and the Weatherhead Center for International Affairs at Harvard. 


\section{Real Convergence and Euro Adoption in Central and Eastern Europe: Trade and Business Cycle Correlations as Endogenous Criteria for Joining EMU}

Ten countries accede to the European Union in 2004, including five in Central Europe and the three Baltic republics (along with Cyprus and Malta). Should they also join the European Monetary Union, as envisioned in the Maastricht Treaty? The advantages of belonging to such a currency area are fairly straightforward. They include most notably the promotion of trade and growth. The disadvantages are a bit more complicated, but include most notably the loss of the ability to pursue an independent monetary policy. ${ }^{1} \quad$ What would it take for the advantages to outweigh the disadvantages? One standard textbook criterion is a particular kind of convergence of the candidate economy to the economy of euroland: a synchronization of the business cycle or what is called in the jargon "symmetry of shocks." If the candidate country experiences economic downturns when and only when the rest of EMU experiences economic downturns, it will not be giving up much to allow its monetary policy to be set in Frankfurt. The interest rates that suit the rest of EMU are likely to suit it as well. If cyclical correlation is low, on the other hand, having to accept the interest rate constraint is more likely to be a hardship.

To be sure, there are other possible definitions of real convergence. A second one is a similar structure of the economy, e.g., similar shares of agriculture versus manufacturing. But this should not be a criterion for adopting the euro. True, differences in composition of the economy can be a source of asymmetric shocks, for example in the event of a fall in world prices for agricultural commodities. But differences in composition are also a primary source of trade benefits.

A third definition of real convergence is similar levels of productivity, per capita income, and relative prices of non-traded goods. The relevance will be considered in Section 4 of the paper. But our central focus in most of the paper will be on the first definition of real convergence, synchronized or correlated business cycles.

We will particularly emphasize the endogeneity of cyclical correlations with respect to the decision to seek economic and monetary integration in the first place. The argument is that a link to the euro, like accession to EU, promotes trade with Western Europe, which in turn raises the cyclical correlation, which in turn makes the country in question a better candidate for EMU. That the creation of a common currency could alter patterns of international trade was one of the original motivations of the architects of EMU. Nevertheless, it is only relatively recently that academic researchers have found

\footnotetext{
${ }^{1}$ Frankel (2004) offers a more complete review of the arguments for fixed versus floating exchange rates in emerging markets.

2 The author would prefer to reserve the word "symmetry" to describe a structure in which, e.g., the Central European countries all have the same correlation patterns as each other, regardless whether those correlation numbers are high or low. Unfortunately, the literature long ago adopted symmetry of shocks as a synonym for cyclical synchronization or correlation.
} 
convincing evidence that this is a major effect. This paper will explain what we have learned from recent research on: (1) the effect of common currencies on trade among members, ${ }^{3}(2)$ the further implications for the benefits of a common currency (3) the further implications for the costs of a common currency as reflected in cyclical correlations -- an important, but endogenous, criterion for membership in an optimum currency area. (The well-known theory of optimum currency areas weighs the advantages of fixed exchange rates versus the advantages of floating. ${ }^{4}$ ) The paper concludes with: (4) thoughts on the bottom line for the question whether countries of Central and Eastern Europe are ready to join EMU.

\section{(1) The effect of common currencies on trade among members}

Until relatively recently, economists had been skeptical whether a reduction in exchange rate variability gives a substantial boost to trade. The skepticism had both theoretical and empirical grounds. Theoretically, the argument was that importers and exporters can hedge exchange rate uncertainty. Empirically, econometric studies found little evidence that exchange rate variability had an adverse effect on trade.

The problem with the theoretical argument, however, is that forward and futures markets (1) don't exist for most countries and for most longer-term horizons, (2) come with transactions costs when they do exist, and (3) come also with risk premia, which can drive a wedge between the forward rate and the expected future spot rate. The problem with the empirical evidence was that it (1) was mostly based on time series, where it was difficult to sort out other influences on trade, and (2) was mostly based on large industrialized countries. ${ }^{5}$ When smaller countries were included in cross-section studies, some effects started to show up. This was particularly true when looking at studies of bilateral trade. Data on trade among 100 countries offer 9900 observations for each year (=100x99). That is a lot of data, which allows the researcher to control for such other important determinants of trade as country size, bilateral distance, common borders, and so on, thereby obtaining better estimates. ${ }^{6}$

The most important discovery was made by Andrew Rose (2000), when he looked at a data set that included many very small countries and dependencies. To begin with, he found a statistically significant effect of bilateral exchange rate variability on bilateral

\footnotetext{
${ }^{3}$ Not considered here is the effects of EMU on those who stay out. If there were evidence of trade diversion from monetary union, it would suggest that periphery countries would be worse off remaining outside of EMU than they would be if EMU had never happened. Fortunately, the evidence seems to go the other way. The Frankel and Rose (2002) estimates of currency union effects reject the hypothesis of trade-diversion in general. The results of Micco, Stein, and Ordoñez (2002), which are updated to 2001, find the same with respect to UK-EMU trade in particular. The (limited) evidence is reviewed in Frankel (2003).

${ }^{4}$ Mundell (1961), of course, coined the phrase "optimum currency area." Tavlas (1992) surveyed the literature.

${ }^{5}$ Surveys of this earlier literature are included in Edison and Melvin (1990) and Goldstein (1995).

6 The gravity model is comprehensively explained in Frankel (1997). Applications to the European Community include Havrylyshyn and Pritchett (1991), Hamilton and Winters (1992), Brada (1993), and Winters (1997).
} 
trade. But, beyond that, he found a large effect of common currencies on bilateral trade. Enough small countries use some other country's currency (most of them either the US dollar, French franc, pound sterling, Australian or New Zealand dollar, or South African rand) that it was possible to isolate the effect. His remarkable estimate, which by now he has replicated in various forms many times, was that a common currency triples trade among members.

A threefold effect is very large, and the finding was, understandably, greeted with a lot of skepticism. There are four grounds for skepticism. First, one can not infer from cross-section evidence what would be the effect in real time of countries adopting a common currency. Second, the statistical association between currency links and trade links might not be the result of causation running from currencies to trade, but might arise instead because both sorts of links are caused by a third factor, such as colonial history, remaining political links, complementarity of endowments, accidents of history and so forth. Third, the estimated effect on trade (and on income, to be discussed in the next section) just seems too big to be believable. Fourth, Rose's evidence came entirely from countries that were either small (e.g., Ireland, Panama, or African members of the CFA franc zone) or very small (e.g., Kiribati, Greenland, Mayotte), and so it was not clear that the estimates could be extended to larger countries.

While each of these four arguments has some validity, to each there is a better response than one might expect.

First, regarding the time dimension, subsequent research on time series data finds that a substantial share of the tripling that Rose had estimated from the cross-section data (which is presumably the long-run effect) shows up within a few decades of a change. Using a 1948-1997 sample that includes a number of countries that left currency unions during that period, Glick and Rose (2001) find that trade among the members was twice as high in the currency union period as afterwards. This suggests that roughly two thirds of the tripling effect may be reached within three decades of a change in regime. (This reasoning assumes symmetry with respect to entry and exit from currency unions.)

Second, regarding the possible influence of third factors, Rose has done a thorough job of controlling for common languages, colonial history, and remaining political links. The large estimated effect of a common currency remains. It seems very possible that there remain other third factors (e.g., accidents of history) that influence both currency choices and trade links. Nevertheless, Rose's various extensions of the original research - these robustness tests together with the time series results -- reduce the force of this critique. ${ }^{7}$

\footnotetext{
${ }^{7}$ Many of the critiques of the Rose results, after pointing out the endogeneity problem or one of the other legitimate problems, offer an alleged way to address it, and then report that the currency union effect disappears. See Rose (2001) for a reply to one, and his website (http://faculty.haas.berkeley.edu/arose/RecRes.htm\#CUTrade) for more. My own view is that many of these responses in effect throw out most of the data, one way or another, in the name of addressing the (correctly identified) issues of endogeneity or country size. Since the finding of statistical significance only arose when Rose put together a large enough data set for it to show up, there is little information gained in reducing the data set sharply and then noticing the loss in statistical significance.
} 
Third, regarding the surprisingly large magnitude of the estimates, it is important to take account of something else that we have learned in recent years. That is findings of strong home country bias in trade, which are especially surprising in light of all one hears about globalization. Many studies have found that people trade with their fellow citizens far more easily than with those living in other countries. This finding emerges whether one looks at the volume of trade flows between locations, or at the ability of arbitrage to keep prices in line across locations. It holds even when one controls for the effects of distance, trade barriers, and linguistic, social and historical differences. It holds even between the US and Canada. The best-known finding is that Canadian provinces are 20 times more prone to trade with each other than with US states. ${ }^{8}$ This estimate was cut very roughly in half after the Canadian-US FTA went into effect, ${ }^{9}$ and has been cut further when controlling for a few more factors. ${ }^{10}$ Nevertheless, a substantial bias remains even in this case, roughly on the order of threefold. The home country bias must certainly be higher for most other country pairs. ${ }^{11}$

Similarly, studies of the ability of arbitrage to narrow price differentials find that crossing the US-Canadian border discourages trade more than does traveling the entire length of Canada, ${ }^{12}$ and that the barrier is even greater for other pairs of countries. ${ }^{13}$ What can explain these remarkable findings of home bias in both quantity data and price data? The difference in currencies is not an implausible explanation, given the paucity of alternative candidates. ${ }^{14}$

Regarding the applicability of the results to large countries, we will not know for sure until enough time passes to yield a verdict on the EMU experiment. It would seem plausible that very small geographical units (the Kiribatis) are so dependent on international trade -- due either to inadequate scale of the domestic market or to insufficiently diversified factors of production -- that strategies such as currency unions or free trade areas would have a larger pay-off for them than for larger, more selfsufficient, economies. But there are two counterarguments. First, Rose has tested whether there are any non-linearities among his currency union sample, e.g., any

\footnotetext{
${ }^{8}$ McCallum (1995).

${ }^{9}$ Helliwell (1998).

${ }^{10}$ Wei (1996).

${ }^{11}$ Using the same gravity methodology, Nitsch (1997) finds that intra-national trade within European countries is about seven times as high as trade with EU partner countries of similar size and distance.

${ }^{12}$ Engel and Rogers (1998).

${ }^{13}$ Parsley and Wei (2000, 2001).

${ }^{14}$ The currency union variable ranks in magnitude and explanatory power roughly equal with the FTA variable, behind the colonial relationship, and ahead of common language and the residual political union effect. This claim is confirmed by Rose and van Wincoop (2001), who estimate that half the typical border barrier is due to different sovereign monies.
} 
difference between the effects among units that are merely small and those that are very small. He found no significant difference. Second, the home country bias seems to be linear, regardless of the size of the country. That is, if two small units join together, thereby doubling the size of the economy, the ratio of trade to GDP falls -- i.e., home country bias increases -- as much (roughly by .2, in log form) as when two large units join together. ${ }^{15}$ To the extent that currencies explain this, the effect does not seem to be limited to small countries.

Finally, we now have four years of data since EMU went into effect in January 1999. Econometricians have updated the gravity estimates to see what can be learned from the record so far. Micco, Stein, and Ordoñez (2003) find that for pairs of the 12 countries that joined EMU, trade has increased significantly. The estimated effect is on the order of 15 percent beyond what could be explained by growth and other factors actually a range of 6 to 26 percent, depending on the use of country and year dummies, with a larger set of 22 industrialized countries. Micco, Stein, and Ordoñez (2002)'s estimates of "differences in differences," estimate between 1992 and 2001 the boost to intra-EMU trade to have been 18 to 35 percent, depending on whether one uses countrypair dummies, or instead conditions on the standard gravity variables. These magnitudes are less than in the Rose studies. As the authors quite reasonably point out, however, the effects are not only statistically significant but also economically important, especially considering that the sample covers only the first four years of EMU, a period in which the Euro did not even circulate.

Other evidence confirms the finding. Bun and Klaasen (2002) also update gravity estimates, and find that "the euro has significantly increased trade, with an effect of $4 \%$ in the first year" and a long-run effect projected to be about 40\%. Takata (2002, p. 11) calculates that the UK-euroland intensity of trade rose gradually in the early 1990s, and sharply in 1999-2000. (Trade intensities are more rudimentary estimates than full gravity models, but are much easier to compute and usually give similar answers regarding changes over time.) Studies with price data so far have tended to confirm that the euro is facilitating arbitrage among the markets of member countries. ${ }^{16}$ It seems clear that the trade effects of monetary union are not, after all, limited to small countries.

\section{(2) The benefits of monetary union}

Boosting trade is of interest primarily as a determinant of economic performance. (Non-economic motivations for encouraging trade, such as binding countries together politically, are outside the scope of this study.) But there are several sorts of ways that an increase in trade among members of a group feed into the question of the economic

\footnotetext{
${ }^{15}$ Also, thinking ahead to estimates of the effects on growth discussed in section 2, the long-run effect of an increase trade on income seems to be the same for large countries and small. Frankel and Rose (2002).

${ }^{16}$ Looking at price data across pairs of European cities, Rogers $(2001,2002)$ finds evidence of convergence in the 1990s. In the European auto market, Goldberg and Verboven (2001) find gradual convergence over the period 1970-2000.
} 
advisability of opting for a common currency. It can influence the benefits of a common currency, or the costs. 
Table 1: The Effect of Currency Union Membership on Aggregate Trade/GDP

\begin{tabular}{|r|c|c|c|c|c|}
\hline Currency Union & .12 & .19 & .10 & .26 & .14 \\
& $(.02)$ & $(.03)$ & $(.02)$ & $(.04)$ & $(.02)$ \\
\hline Political Union & .12 & .41 & .19 & .04 & .13 \\
& $(.03)$ & $(.05)$ & $(.03)$ & $(.02)$ & $(.03)$ \\
\hline Log Real GDP per Capita & .12 & .06 & .12 & .25 & .15 \\
& $(.01)$ & $(.01)$ & $(.01)$ & $(.02)$ & $(.01)$ \\
\hline Log Population & -.19 & -.17 & -.23 & -.07 & -.17 \\
& $(.01)$ & $(.01)$ & $(.003)$ & $(.03)$ & $(.01)$ \\
\hline Log Land Area & -.06 & -.08 & & & -.05 \\
& $(.01)$ & $(.01)$ & & & $(.01)$ \\
\hline Island & -.10 & -.02 & & & -.07 \\
& $(.02)$ & $(.03)$ & & & $(.02)$ \\
\hline Landlocked & -.04 & .01 & & & -.04 \\
& $(.02)$ & $(.03)$ & & & $(.02)$ \\
\hline Remoteness & -.15 & .06 & -.27 & -.67 & -.12 \\
& $(.03)$ & $(.05)$ & $(.03)$ & $(.15)$ & $(.03)$ \\
\hline Log RoW Real GDP & .37 & .19 & .41 & .25 & 2.89 \\
& $(.02)$ & $(.04)$ & $(.02)$ & $(.03)$ & $(.15)$ \\
\hline Number of Observations & 4236 & 1777 & 4236 & 4236 & 4236 \\
\hline Rog & .57 & .60 & .55 & .88 & .59 \\
\hline RMSE & .416 & .396 & .423 & .228 & .409 \\
\hline & & & & Country & Year \\
\hline & & & & Fixed & Fixed \\
\hline & & & & Effects & Effects \\
\hline & & & & \\
\hline
\end{tabular}

Regressand is log of trade/GDP, from Penn World Table.

(Robust standard errors recorded in parentheses.)

Source: Frankel and Rose "Estimating the Effect of Currency Unions on Trade and Output," NBER Working Paper No. 7857, August 2000, Table A2.

The first respect in which trade patterns are relevant has to do with advantage of a common currency from the viewpoint of exporters and importers. The fact that the elimination of exchange rate uncertainty makes life easier for those engaged in trade will be more important, the higher is the share of trade in GDP, even if the level of trade does not change. Also a fixed exchange rate will help stabilize the price level, the higher is the share of trade in GDP. For these reasons, McKinnon (1963) argued that a key factor determining the advisability of fixing the exchange rate is the ratio of tradable goods to GDP. Thus openness has long been on the standard textbook list of optimum currency 
area criteria. One implication is that if trade among the members of the EU is increasing over time, then they will satisfy the optimum currency area criteria more strongly in the future than in the past. A related implication is that even if a country does not satisfy the optimum currency area criteria ex ante, if it goes ahead and joins a currency area anyway, and enough time passes to increase trade with other members substantially as a result of the common currency, then again it may satisfy the optimum currency area criteria in the future. In Frankel and Rose $(1996,1998)$, we called this the endogeneity of the optimum currency area criterion.

The second factor has to do with the long-run determination of growth. Trade is not just another sector. Theory and empirical evidence suggest that trade is good for the level or growth rate of income. Currency unions raise openness, and openness raises real income. Frankel and Rose (2002) combine estimates of the effects of a common currency on trade and the follow-on effects of higher trade on GDP, to derive estimates of the effects of common currencies on GDP. Table 1 shows that membership in a typical currency union raises the ratio of trade to GDP by an estimated 10 to 26 percentage points. But joining a currency union with particularly important trading partners (e.g., large and close neighbors) can have a larger impact. For example, if Poland were to join EMU and thereby triple trade with euro-countries, its ratio of total trade to GDP would eventually more than double from .50 to 1.12 . Once the increase in trade was realized, the estimated effect would be to raise real income by 20 percent over the subsequent 20 years, quite a substantial effect, if it is believed. Similarly, if Hungary were to join and thereby triple trade with euroland, its ratio of trade to GDP would also eventually more than double (from .76 to 1.83 ), and its real income increase by 35 percent. $^{17}$

\section{(3) The implications of trade patterns for the costs of a common currency: asymmetric shocks}

The last factor concerns cyclical fluctuations. If joining a currency union has advantages, such as promoting trade or stabilizing the price level, what is the countervailing attraction of retaining an independent currency? Why don't all countries fix their exchange rates or join currency unions? The most important advantage of flexible exchange rates is to retain the ability to respond to cyclical downturns by means of monetary policy -- a reduction in real interest rates, or a real depreciation of the currency or both -- and to respond to cyclical booms in the opposite direction. But this advantage is less important if the domestic economy is highly correlated with the other countries in a prospective currency area (i.e., if shocks are usually "symmetric"), because the changes in monetary policy that the other member countries choose will also be appropriate for the domestic economy. This is another key tenet of optimum currency area theory. But cyclical correlations are not timeless unchanging parameters. If trade among members of a currency area increases, then the cyclical correlation is likely to change as well.

\footnotetext{
${ }^{17}$ Those calculations take existing trade patterns as the baseline. Presumably trade between Hungary/Poland and EU members will actually continue to increase between now and the time that an EMU counterfactual becomes relevant.
} 
Artis and Zhang (1995) find that most European countries' incomes were more highly correlated with the U.S. during 1961-79, but (with the exception of the UK) became more highly correlated with Germany after joining the ERM. ${ }^{18}$ Fatas (1997) also found increasing correlation within Western Europe. More recently, Darvas and Szapary (2003) find that with the advent of EMU, the synchronization of GDP (and components of GDP) among the members has continued to increase.

In Frankel and Rose (1998), we found on a broad cross-section of industrialized countries that an increase in bilateral trade raises the bilateral cyclical correlation. The geographic determinants of bilateral trade, via the gravity model, are used as instrumental variables to deal with what is otherwise likely to be the endogeneity of trade. (In other words, a pair of countries could show high trade links together with high cyclical correlation, but the connection could be spurious: both could be the result of currency links.) Clark and van Wincoop (2001) find that the historical lack of cyclical synchronization within Europe, as compared to within the United States, is explained by the lower level of internal trade (and to a lesser extent the higher degree of sectoral specialization).

Calderon, Chong and Stein (2002) point out that the experience of developing countries might be different, in that the composition of their economies differs from highincome countries. They extend the finding that trade links lead to cyclical correlation to a larger sample of 147 countries, a majority of them developing countries, again using the gravity model to control for the endogeneity of trade. They find that the estimated effect on cyclical correlations is not quite as strong for developing countries as it is among pairs of industrialized countries. They attribute the difference to the dominance of interindustry trade for developing countries, versus intra-industry trade among high-income countries. $^{19}$

Researchers have begun to look at the cyclical patterns in Central and Eastern Europe. Boone and Maurel $(1998,1999)$ find high correlations of CEE countries with the German economy in particular. Fidrmuc (2004) examines all European countries, using output data through 2001; he confirms that correlations with the German economy increased for Hungary and Poland during the 1990s, and that the correlation for Hungary is one of the highest in Europe, but that the correlations are much lower in other CEE countries. $^{20}$

Darvas and Szapary (2003) have recently examined eight Central and Eastern European (CEE) countries joining the EU in 2004. They find that three have achieved a high degree of synchronization with the EMU economy: Hungary, Poland and Slovenia

\footnotetext{
${ }^{18}$ Eichengreen pointed out that such correlations may be the result of the loss of monetary independence, rather than of the increased trade. But Clark and Wincoop find that a common monetary policy is not, in fact, the explanation for why the cyclical correlation among regions of the United States is higher than among European countries over the past few decades.

${ }^{19}$ Torres and Vela (2003) find that growing trade links between Mexico and the U.S. have synchronized the business cycle.

${ }^{20}$ Others who find increasing cyclical correlations for some CEE countries include Babetski, Boone and Maurel (2002) and Frenkel and Nickel (2002).
} 
during the 1998-2002 period, as compared to 1993-97. The implication is that these three now best satisfy the convergence criterion for joining the EMU optimum currency area. The lesser EMU correlation for the Czech and Slovak republics is attributed to financial crises in the late 1990s, and the lack of any EMU correlation for the Baltics is attributable to their greater relative exposure to Russia and Sweden. It is no coincidence that the EU makes up a higher share of the exports of Hungary, Poland and Slovenia than of the exports of the other CEECs (Figure 6 in Darvas and Szapary). One could also note the importance of geographical proximity in determining trade links and cyclical correlations: those CEE countries that border the euroland are the ones with high EMU trade links and correlations, but for the Czech exception.

The effect of trade on cyclical correlation holds as much when high bilateral trade originates in low bilateral exchange rate variability or adoption of a common currency as it does when the bilateral trade originates in proximity, free trade areas, or other factors. This is another instance of the endogeneity of the optimum currency area criteria. A country is more likely to be suited to join a monetary union ex post than ex ante, because the cyclical correlation will have gone up in the meantime.

The internal history of the United States is consistent with these findings. Rockoff (2000) argues that it took 150 years before the United States met the criteria for an Optimum Currency Area, asymmetric regional shocks having posed severe problems for much of its history.

All these findings contradict an earlier surmise of Eichengreen (1992, pp.14-16), Bayoumi and Eichengreen (1994, pp.4-5), and Paul Krugman (1993). These authors suggest that, because a higher trade level would lead to greater specialization, it would also lead to lower synchronization of shocks. ${ }^{21}$ Their view that specialization works against common currencies, and that diversification of the economy works in favor of it, goes back to Kenen (1969).

In the growing literature on endogenous optimum currency area criteria, it is common to assume that the debate whether trade raises cyclical correlations as Frankel and Rose (1998) claim $^{22}$, or lowers it as Krugman and Eichengreen claim, turns on

21 "Theory and the experience of the US suggest that EC regions will become increasingly specialized, and that as they become more specialized they will become more vulnerable to regionspecific shocks. Regions will, of course, be unable to respond with counter-cyclical monetary or exchange rate policy" (Krugman, 1993, p.260). Hughes Hallett and Piscitelli (1999) call this "the traditional view," and add some modeling of demand-driven transmission which had otherwise been missing from this debate. [The No Campaign $(2002$, p. 40) in the UK is among those asserting that EMU is likely to generate a degree of specialization that undermines the insulation against shocks necessary for a common currency.]

${ }^{22}$ Evidence in Honkapohja and Pikkarainen (1992) also supports the idea that countries with a high degree of specialization are more likely to find it desirable to peg their exchange rate. But Imbs (1999) claimed that trade is not, after all, a big determinant of cyclical correlations. According to Kalemli-Ozcan, Sorensen, and Yosha $(1999,2001)$, the degree of risk-sharing via integrated capital markets is the interesting determinant of industrial specialization and cyclical symmetry. 
whether the trade is primarily intra-industry or inter-industry. Fidrmuc $(2001,2004)$ and Imbs (2003) extend the econometric estimation to take specific account of intra-industry trade as a determinant of cyclical correlation. The reasoning is that shocks in a world of inter-industry trade take the form of shifts from one industry to another: one country's loss is the other's gain, giving negative correlations. In a world of intra-industry trade, industry shifts are assumed to affect all the product varieties produced in different countries, thus giving positive correlations. Tests by these authors seem to confirm the argument that intra-industry specialization is in fact the source of positive cyclical correlations, driving out total bilateral trade as an explanatory factor.

But it seems to this author that several things are potentially wrong with the argument. First, a large share of trade today is in inputs and intermediate products. Think of iron ore that is made into steel, which is in turn made into machinery parts, which are made into the finished machine tool that is used in the production of something else. Or a similar story with computers. A positive shock at one point in the chain of value-added in one country will tend to have positive spillover effects, at the other points along the chain in other countries. ${ }^{23}$ Thus trade in inputs and intermediate products gives rise to positive correlations; and yet it may be recorded as inter-industry trade.

Nevertheless, this is ultimately an empirical question, as Calderon, Chong, and Stein (2002) point out, and empirical studies such as Fidrmuc (2004) do indeed seem to find that intra-industry trade links are associated with cyclical correlation and inter-industry trade links are not.

The second objection concerns supply versus demand shocks, and may be harder to reject. It is worth stepping back for a moment to realize that we should be more interested in demand shocks than supply shocks. Recall that the point of the whole exercise is to see how much countries are giving up when they give up independent/ discretionary monetary policy. Discretionary monetary policy is not much good at addressing supply shocks anyway. Therefore it doesn't much matter whether you share them with your neighbors or not. ${ }^{24}$ Discretionary monetary policy is more useful in addressing demand shocks. For these, bilateral transmission could come from either intra-industry trade or inter-industry trade. A shortfall in demand, originating for example in a decrease in velocity or a fall in investment, will be transmitted to trading partners as a reduction in demand for imports of all sorts - varieties that are in the same industry as well as products in different industries. If the partners are unable to respond to shocks because they have given up their monetary independence, this will be less of a hardship to the extent that the common monetary policy is determined by a set of countries all experiencing the common loss in demand. But the distinction between intra-industry and inter-industry trade may be less useful than often supposed. The more important question may be demand shocks versus supply shocks. ${ }^{25}$

${ }^{23}$ E.g., Kose and Yi (2001).

${ }^{24}$ Admittedly, having one's own currency is more useful for terms of trade shocks than it is for domestic supply shocks, in that it allows equilibration to external balance without imposing deflation - automatically so in the case of a floating currency.

${ }^{25}$ In this regard, it is interesting that Babetski, Boone and Maurel (2002) find progressive CEEEU convergence for demand shocks over the last decade, but divergence for supply shocks. 


\section{(4) “Convergence:” Are Central and Eastern European countries ready to join EMU?}

The author's feeling is that whether Europe happens to experience a large asymmetric shock within the next few decades will largely determine whether EMU proves on net beneficial or not for its members. The early 1990s saw a German spending boom associated with reunification, which implied a temporary real appreciation of the mark against the pound and other European currencies; fortunately monetary integration had not proceeded so far as to make such a realignment impossible. Today it would not be possible.

One cannot say what will be the important shocks of the future. Their unpredictability is what makes them shocks. Possible shocks that would hit the eastern half of the continent asymmetrically from the west include repetitions of past instability in the former Soviet Union, which might particularly impact the Baltics, or of financial crises such as experienced by the Czech Republic in the late 1990s. In the event of such a shock in the future occurring in one of those countries that are on the path to join EMU, even the other candidates lucky enough to escape the direct impact would likely be hit indirectly. The reason is the contagion phenomenon that has been so evident in past crises: Western Europe during 1992-93, Latin America in 1982, 1994-95 and 1998-99, East Asia during 1997-98, and other emerging markets subsequent to the Russian default of 1998.

Some of the CEE countries probably do not meet the optimum currency area criteria as well currently as do the existing members of EMU. An argument for going ahead and joining anyway is the endogeneity of the OCA criteria. By adopting the euro, they will eventually promote trade with the rest of euroland, and increase the cyclical correlation. The increased trade will in turn further increase the advantages of a common currency, while the increased correlation will reduce the disadvantages of a common currency. Thus the CEE countries may eventually qualify ex post even if they do not ex ante. On the other hand the risks of asymmetric shocks in the meantime are substantial.

Trade links with euroland have risen over the last decade anyway, as trade that had for half a century or more been distorted by enforced dependence on the Soviet Union reverts to more natural patterns. CEE countries now trade roughly as much with euroland as the countries of euroland trade with each other. ${ }^{26}$ Trade with Western Europe can be expected to rise quite a bit more in reaction to the formal accession of the eight to the EU in 2004. Along with trade links, cyclical correlations can be expected to rise further. The shift in trade patterns and correlations will be drawn out over time. The reason is that the effects of membership in an FTA or common market develop with long lags. ${ }^{27}$ Therefore the risk-averse strategy would be to wait five years or more for EU membership to take hold and integration to proceed further. By then, the convergence will have proceeded far enough that asymmetric shocks and contagion pose less of a danger. Another factor working in favor of waiting is the opportunity to learn by

\footnotetext{
${ }^{26}$ Darvas and Szapary (2003), Backe and Thimann (2004, Charts 2.1 and 2.2), and Boeri (2004, Figure 1).

${ }^{27}$ The lags appear in the gravity estimates, e.g., Eichengreen and Irwin (1998).
} 
watching the experiment unfold in euroland (and - more unpredictably - among any additional joiners).

So far, this paper has interpreted "convergence" to refer to the synchronization of business cycles, i.e., correlation of unanticipated shocks, that would reduce the need for individual countries to retain their own monetary policy. But another interpretation of convergence would look for narrowing in the gaps of productivity, or real income, between East and West. Levels of productivity and real income in the East are substantially below those in the West, but a reasonable expectation is that the former will increase more rapidly than the latter. It is not that low-income countries can always expect to catch up with rich countries (unconditional convergence). Rather, low-income countries that have the necessary preconditions or that become successfully integrated with the economies of richer neighbors, do tend to close the gap over time. In particular, economic integration with more advanced neighbors seems to accelerate productivity growth. For example, Coe and Helpman (1995) argue that intermediate goods embody technology, and find that countries' productivity levels are positively affected by measures of foreign partners' research and development weighted by bilateral import shares. ${ }^{28}$ Indeed, one-seventh of the gap in per capita incomes vis-à-vis the EU 15 has already been closed over the last ten years. (Relative to EU income, incomes among the CEE eight had an unweighted average of 41 percent in 1993, but had risen to 48 percent in 2002. ${ }^{29}$ )

The Balassa-Samuelson effect predicts that as a consequence of rapid productivity growth in Central and Eastern Europe, these countries will experience increases in their relative prices of nontraded goods and services, such as housing, and thus will experience real appreciation of their currencies. In this respect they will follow in the footsteps of Greece, who has experienced a trend of real appreciation over the last ten years. Some estimates for CEE countries predict real appreciation of about two per cent per year. ${ }^{30}$ Most of the eight have already experienced substantial real appreciation over the last five or ten years, as Table 2 records. If they retain their own currencies, and this trend in relative prices continues, it will probably show up partly as nominal appreciation of their currencies. But if they have joined EMU before income convergence is achieved, the trend will show up entirely as a higher inflation rate in the new member countries than in the rest of euroland. One issue is the parity at which they enter EMU. But even assuming these countries are able to adjust their parities to the right competitive level before entering EMU, or more precisely, before entering the two-year probationary period, the Balassa-Samuelson effect predicts that there will continue to be upward pressure on their price levels in the future. Once they have joined EMU there will be no good way to address it.

28 The many other authors who have examined how income convergence can be fostered by trade, which in turn is partly driven by geography, include: Baldwin, Martin and Ottaviano (1998), Ben-David and Rahman (1996), Bloom, Canning and Sevila (2002), Bottazi and Peri (1999), Keller (2001), Quah (1996), and Redding and Venables (2000) .

29 Calculations based on data in Box 2 of Kenen and Meade (2003).

30 Estimates summarized in Buiter and Grafe (2002) and Kenen and Meade (2003). 
Table 2:

Trends of real appreciation among countries acceding to the EU over past decade

\begin{tabular}{|c|c|c|c|c|}
\hline Country & Measure of Real Exchange Rate & Period & $\begin{array}{l}\text { Average Rate } \\
\text { Real Apprectn. }\end{array}$ & Source \\
\hline \multirow[t]{2}{*}{ Bulgaria } & CPI-based & $1992-2002$ & 0.076 & IMF International Financial Statistics \\
\hline & $\begin{array}{l}\text { CPI-based, weights: three currencies } \\
\text { with the largest share in the trade turnover: } \\
\text { USD }-57.24 \% \text {, DEM }-41.98 \%, \text { CHF }-0.71 \% \text {. }\end{array}$ & $1997-2002$ & 0.028 & Bulgarian National Bank \\
\hline \multirow[t]{4}{*}{ Czech Republic } & PPI-based, weights: foreign trade turnover $(2000=100)$ & $1996-2002$ & 0.029 & Ceska Narodni Banka \\
\hline & CPI-based, weights: foreign trade turnover $(2000=100)$ & $1996-2002$ & 0.042 & \\
\hline & $\begin{array}{l}\text { Labor Cost Index-based (industry and services), weights: } \\
\text { foreign trade turnover }(2000=100)[1]\end{array}$ & $1996-2003$ & 0.077 & \\
\hline & $\begin{array}{l}\text { Labor Cost Index-based (manufacturing), weights: } \\
\text { foreign trade turnover }(2000=100)[1]\end{array}$ & $1996-2003$ & 0.078 & \\
\hline Estonia & $\begin{array}{l}\text { Trade-weighted basket of currencies converted to an index } \\
(1997=100) \text {, adjusted for relative price movements. }\end{array}$ & $1992-2002$ & 0.130 & Economist Intelligence Unit \\
\hline \multirow[t]{3}{*}{ Greece } & $\begin{array}{l}\text { Trade-weighted basket of currencies converted to an index } \\
(1997=100) \text {, adjusted for relative price movements. }\end{array}$ & $1992-2002$ & 0.028 & \\
\hline & Unit Labor Cost-based & $1992-2002$ & 0.012 & IMF International Financial Statistics \\
\hline & $\begin{array}{l}\text { NEER (value of currency against a weighted average of } \\
\text { several foreign currencies) divided by a price deflator }(1995=100)\end{array}$ & $1992-2002$ & 0.005 & World Bank World Development Indicators \\
\hline \multirow[t]{4}{*}{ Hungary } & CPI-based & $1992-2002$ & 0.030 & IMF International Financial Statistics \\
\hline & CPI-based $(2000=100)[2]$ & $1992-2003$ & 0.032 & National Bank of Hungary \\
\hline & PPI-based $(2000=100)[2]$ & $1992-2003$ & 0.020 & \\
\hline & Unit Labor Cost-based [1] & $1995-2003$ & 0.003 & \\
\hline \multirow[t]{2}{*}{ Ireland } & CPI-based & $1992-2002$ & -0.008 & IMF International Financial Statistics \\
\hline & Unit Labor Cost-based & $1992-2002$ & -0.063 & \\
\hline \multirow[t]{6}{*}{ Latvia } & CPI-based, Against currencies of developing countries [2] & $1996-2003$ & 0.007 & Bank of Latvia \\
\hline & CPI-based, Against currencies of industrial countries [2] & $1996-2003$ & 0.029 & \\
\hline & PPI-based, Against currencies of developing countries [2] & $1996-2003$ & -0.010 & \\
\hline & PPI-based, Against currencies of industrial countries [2] & $1996-2003$ & 0.012 & \\
\hline & Wage-based, Against currencies of developing countries [2] & $1996-2003$ & 0.018 & \\
\hline & Wage-based, Against currencies of industrial countries [2] & $1996-2003$ & 0.071 & \\
\hline \multirow[t]{4}{*}{ Lithuania } & CPI-based (June 1993 = 100) Against All Currencies [2] & $1993-2003$ & 0.070 & Lietuvos Bankas \\
\hline & CPI-based (June 1993 = 100) Against EU [2] & $1993-2003$ & 0.118 & \\
\hline & CPI-based (June 1993 = 100) Against CEE Currencies [2] & $1993-2003$ & 0.053 & \\
\hline & CPI-based (June 1993 = 100) Against CIS Currencies [2] & $1993-2003$ & 0.044 & \\
\hline \multirow[t]{2}{*}{ Poland } & CPI-based & $1992-2002$ & 0.030 & IMF International Financial Statistics \\
\hline & $\begin{array}{l}\text { Trade-weighted basket of currencies converted to an index } \\
(1997=100) \text {, adjusted for relative price movements. }\end{array}$ & $1992-2002$ & 0.044 & Economist Intelligence Unit \\
\hline Romania & CPI-based & $1992-2002$ & 0.065 & \\
\hline \multirow[t]{6}{*}{ Slovakia } & CPI-Basket of SK & $1992-2002$ & 0.038 & National Bank of Slovakia \\
\hline & PPI-Basket of SK & $1992-2002$ & 0.025 & \\
\hline & CPI-8 trading partners, ex-Czech Rep. & $1992-2002$ & 0.042 & \\
\hline & PPI-8 trading partners, ex-Czech Rep. & $1992-2002$ & 0.029 & \\
\hline & CPI-9 trading partners, incl. Czech Rep. & $1992-2002$ & 0.011 & \\
\hline & PPI-9 trading partners, incl. Czech Rep. & $1992-2002$ & 0.003 & \\
\hline Slovenia & $\begin{array}{l}\text { Trade-weighted basket of currencies converted to an index } \\
(1997=100) \text {, adjusted for relative price movements. }\end{array}$ & $1993-2002$ & 0.003 & Economist Intelligence Unit \\
\hline \multirow[t]{2}{*}{ Spain } & CPI-based & $1992-2002$ & -0.016 & IMF International Financial Statistics \\
\hline & Unit Labor Cost-based & $1992-2002$ & -0.008 & \\
\hline
\end{tabular}

Full convergence of real incomes can be expected to take a very long time. No country should be expected to wait this long to join EMU, if joining is otherwise attractive. But the absence of income-convergence suggests that the ECB would have to take into account the Balassa-Samuelson effect. After the expansion of EMU, it might be appropriate for the ECM to allow countries that experience the Balassa-Samuelson effect to run inflation rates above the union-wide target, so as to avoid imposing deflation on the original core members. 
The bottom line is that waiting for substantial convergence of per capita incomes is too long to wait. But the CEE countries will meet the optimum currency area criteria for joining the euro-12 better in the future than they do today. Waiting five years for further trade integration and cyclical correlation between the CEE and EMU is not necessarily too long.

According to the terms of the Maastricht Treaty, the new members must wait anyway, until certain conditions are met. The four "convergence criteria" that aspirants must legally satisfy before joining EMU are price stability, budget discipline, exchange rate stability, and convergence of long-term interest rates. They are sometimes called "nominal convergence," as opposed to the "real convergence" that has been the subject of this paper.

The four Maastricht conditions, particularly the fiscal criterion, are not very closely based on international monetary theory. ${ }^{31}$ The problem is not that different criteria might be relevant for transition countries than for their more advanced neighbors, nor even just that different details of the specification are appropriate now that EMU is already in existence. Rather, the four convergence criteria of the Maastricht Treaty never did correspond well to the standard criteria that textbooks lay out for Optimum Currency Areas: trade integration, cyclical synchronization, labor mobility and fiscal cushions. New research on currency boards and dollarization in the 1990s produced a third set of criteria that were supposed to qualify a country to be able to live without its own currency in an age of financial integration. A short rendition of those criteria includes: popular support for integration with neighbors, high private use of the euro or dollar, high pass-through, and, especially, a strong need to import monetary stability arising for example from a history of hyperinflation. But the Maastricht convergence criteria do not correspond to this 1990s list much better than they correspond to the traditional optimum currency area list.

Nevertheless, the delay that the Maastricht criteria would impose may not be too different from the sort of delay that is in any case desirable. It depends how strictly they are interpreted. ${ }^{32}$

Heroes in Greek mythology were always being assigned seemingly irrelevant errands. King Aegeus placed his sword and sandals under a large stone, and left behind instructions that only when his son Theseus was able to lift the stone and take the sword

31 Buiter, Corsetti and Roubini (1993) and Frankel (1993), among others, considered the possible rationales for having fiscal criteria as a pre-condition. Recent experience with the Stability and Growth Pact bears out the earlier economist warnings. It is difficult to ask CEE countries, in particular, to satisfy strict limits on their budget deficits at a time when major western European countries are blithely ignoring those same limits. One possible interpretation, however, is that budget discipline is chronically and everywhere in short supply, and that accession to EMU offers a onetime occasion to mobilize the political support necessary to achieve painful fiscal consolidation. Under this theory, Maastricht uses EMU as an excuse.

${ }^{32}$ Some, including Buiter and Grafe (2002) and Kenen and Meade (2003) argue for a revised interpretation of the criteria that would lead to speedy accession to EMU. European Commission officials, however, have declared a stricter interpretation - including exchange rate margins of 2 $1 / 4 \%$ to be maintained for two years. 
and sandals should he come to Athens to claim his kingdom. Theseus' mother waited before even telling him to try to lift the stone, until he was old enough and strong enough to do it easily. Perhaps the Maastricht criteria will serve as 


\section{References}

Aitken, Norman, 1973, "The Effect of the EEC and EFTA on European Trade: A Temporal Cross-Section Analysis," American Economic Review 63, 881-892.

Angeloni, I., and L. Dedola, 1999, "From the ERM to the Euro: New Evidence on Economic and Policy Convergence Among EU Countries," European Central Bank Working Paper No. 4, May.

Artis, Michael, and Wenda Zhang, 1995, "International Business Cycles and the ERM: Is There a European Business Cycle?" CEPR Discussion Paper No. 1191, August.

Babetski, Jan, Laurence Boone and Mathilde Maurel (2002), "Exchange Rate Regimes and Supply Shocks Asymmetry: The Case of the Accession Countries," CEPR Discussion Paper, No. 3408.

Backe, Peter, and Christian Thimann, 2004, "The Acceding Countries' Strategies Towards ERM II and the Adoption of the Euro: An Analytical Review," European Central Bank, January. This volume.

Baldwin, Richard, Philippe Martin and Gianmarco Ottaviano, 1998, “Global Income Divergence, Trade and Industrialization: The Geography of Growth Takeoffs," Centre for Economic Policy Research Discussion Paper No. 1803, London.

Bayoumi, Tamim, and Barry Eichengreen, 1993a, "Shocking Aspects of European Monetary Unification," in Francesco Giavazzi and Francisco Torres, eds., The Transition to Economic and Monetary Union in Europe, Cambridge University Press, New York.

Bayoumi, Tamim, and Barry Eichengreen, 1993b, "Is There A Conflict Between EC Enlargement and European Monetary Unification," Greek Economic Review 15, no. 1, Autumn, 131-154.

Bayoumi, Tamim, and Barry Eichengreen, 1994, One Money or Many? Analyzing the Prospects for Monetary Unification in Various Parts of the World, Princeton Studies in International Finance no. 76, September, Princeton.

Ben-David, Dan, and Atiqur Rahman, 1996, “Technological Convergence and International Trade," Centre for Economic Policy Research, London, January.

Bloom, David, David Canning and Jaypee Sevila, 2002 "Technological Diffusion, Conditional Convergence, and Economic Growth,” NBER WP no. 8713, Jan.

Boeri,Tito, 2004, Bocconi University, January.

This volume

Boone, Laurence, and Mathilde Maurel, 1998, "An Optimal Currency Are Perspective of the EU Enlargement to the CEECs," CEPR Discussion Paper, No. 2018.

Boone, Laurence, and Mathilde Maurel, 1999, "Economic Convergence of the CEECs with the EU," CEPR Discussion Paper No. 2119.

Bottazi,Laura, and Giovanni Peri, 1999, "Innovation, Demand and Knowledge Spillovers: Theory and Evidence from European Regions,” Centre for Economic Policy Research Discussion Paper No. 2279, Oct.

Brada, Josef C., 1993, "Regional integration in Eastern Europe: prospects for integration within the region and with the European Community." in New Dimensions in Regional Integration, eds. Jaime De Melo and Arvind Panagariya. Cambridge University Press, pp. 319-351. 
Buiter, Willem, Giancarlo Corsetti and Nouriel Roubini, 1993, "'Excessive Deficits': Sense and Nonsense in the Treaty of Maastricht," Centre for Economic Policy Research, London; Economic Policy 16, April, 92-97.

Buiter, Willem, and Clemens Grafe, 2002, "Anchor, Float or Abandon Ship: Exchange Rate Regimes for the Accession Countries", in Banca Nazionale del Lavoro Quarterly Review, No. 221, June, pp. 1-32.

Bun, Maurice, and Franc Klaasen, 2002, "Has the Euro Increased Trade?" University of Amsterdam, October 10 .

Calderon, Cesar, Alberto Chong, and Ernesto Stein, 2002, "Trade Intensity and Business Cylce Synchronization: Are Developing Countries any Different?” InterAmerican Development Bank, December.

Clark, Todd, and Eric van Wincoop, 2001, "Borders and Business Cycles," Federal Reserve Bank of Kansas City RWP 99-07; Journal of International Economics 55, 59-85.

Coe, David, and Elhanan Helpman, 1995, "International R\&D Spillovers," European Economic Review $39,859-887$.

Cohen, Daniel, and Charles Wyplosz, 1989, "The European Monetary Union: An Agnostic Evaluation," in R. Bryant, D. Currie, J.Frenkel, P.Masson, and R. Portes, ed. Macroeconomic Policies in an Interdependent World, Washington DC, Brookings, 311-337.

De Grauwe, Paul, and Wim Vanhaverbeke, 1991, "Is Europe an Optimum Currency Area? Evidence from Regional Data," CEPR Discussion Paper No. 555, London, May.

Darvas, Zsolt, and Gyorgy Szarpy, 2003, "Business Cycle Synchronization in the Enlarged EU: Comovements in the (Soon-To-Be) New and Old Members," Magyar Nemzeti Bank.

Edison, Hali, and Michael Melvin, 1990, "The Determinants and Implications of the Choice of An Exchange Rate System," in Monetary Policy For a Volatile Global Economy, W. Haraf and T. Willett, eds., American Enterprise Institute, Washington, D.C..

Eichengreen, Barry, 1992, "Should the Maastricht Treaty Be Saved?" Princeton Studies in International Finance, No. 74, International Finance Section, Princeton Univ., December.

Eichengreen, Barry, and Douglas Irwin. 1998, "The Role of History in Bilateral Trade Flows," in The Regionalization of the World Economy, J. Frankel, ed., Univ. of Chicago Press, Chicago.

Engel, Charles, and John Rogers, 1994, "How Wide is the Border?" American Economic Review 86, no.5, December 1996, 1112-1125.

Engel, Charles, and John Rogers, 1997. "Regional Patterns in the Law of One Price: The Role of Geography vs. Currencies," in J. Frankel, ed., The Regionalization of the World Economy, Chicago, University of Chicago Press, 1998.

Fatas, Antonio, 1997, “EMU: Countries or Regions? Lessons from the EMS Experience,” European Economic Review 41, 743-751.

Fidrmuc, Jarko, 2001, "The Endogeneity of the Optimum Currency Area Criteria and Intra-Industry Trade,” LICOS Centre for Transition Economics, Katholieke Universiteit Leuven.

Fidrmuc, Jarko, 2004, "The Endogeneity of the Optimum Currency Area Criteria, Intra-Industry Trade, and EMU Enlargement,” Oct. 2002. In Contemporary Economic Policy, 22, no. 1, Jan., pp 1-12.

Frankel, Jeffrey, 1993, "'Comments on Buiter, Corsetti and Roubini," Economic Policy 16, April, 92-97. 
Frankel, Jeffrey, 1997, Regional Trading Blocs in the World Trading System, Institute for International Economics, Washington DC.

Frankel, Jeffrey, 2003, "The UK Decision re EMU: Implications of Currency Blocs for Trade and Business Cycle Correlations," in Submissions on EMU from Leading Academics (H.M. Treasury: London), p.99-109.

Frankel, Jeffrey, 2004, "Experience of and Lessons from Exchange Rate Regimes in Emerging Economies," in Monetary and Financial Integration in East Asia: The Way Ahead, edited by Asian Development Bank (Palgrave Macmillan Press, New York), vol. 2, 91-138.

Frankel, Jeffrey, and Andrew Rose, 1996, "The Endogeneity of the Optimum Currency Area Criterion: An Application to Sweden's Decision on EMU," Background report to the Swedish Government Commission on EMU (in Swedish), Statens Offentliga Utredningar 1996:158.

Frankel, Jeffrey, and Andrew Rose, 1998, "The Endogeneity of the Optimum Currency Area Criterion," The Economic Journal, Vol. 108, No. 449 (July), pp. 1009-25.

Frankel, Jeffrey, and Andrew Rose, 2002, "An Estimate of the Effect of Common Currencies on Trade and Income," Quarterly Journal of Economics, May.

Frankel, Jeffrey, and Shang-Jin Wei, 1995a, Emerging Currency Blocs," in The International Monetary System: Its Institutions and its Future, edited by Hans Genberg, Springer, Berlin, 111-143.

Frankel, Jeffrey, and Shang-Jin Wei, 1995b, "European Integration and the Regionalization of World Trade and Currencies: The Economics and the Politics" in Monetary and Fiscal Policy in an Integrated Europe, edited by Barry Eichengreen, Jeffry Frieden, and Jurgen von Hagen, Springer-Verlag Press, Heidelberg.

Frankel, Jeffrey, and Shang-Jin Wei, 1997, "Regionalization of World Trade and Currencies: Economics and Politics" The Regionalization of the World Economy, J. Frankel, ed., U. of Chicago Press, Chicago, 1998.

Frenkel, Michael, and Christiane Nickel (2002), "How Symmetric Are the Shocks and the Shock Adjustment Dynamics Between the Euro Area and Central and Eastern European Countries?" IMF Working Paper no. 02/222.

Glick, Reuven, and Andrew Rose, 2002, "Does a Currency Union Affect Trade? The Time Series Evidence," NBER Working Paper No. 8396,. European Economic Review, 46, 6 (June) 1125-51.

Goldberg, Pinelope Koujianou, and Frank Verboven, 2001, "Market Integration and Convergence to the Law of One Price: Evidence from the European Car Market," NBER Working Paper No. 8402, July.

Goldstein, Morris, 1995, The Exchange Rate System and the IMF: A Modest Agenda, Policy Analyses in International Economics 39, June, Institute for International Economics.

Hamilton, Carl, and L.Alan Winters. 1992. "Opening Up International Trade in Eastern Europe," Economic Policy (April).

Havrylyshyn, Oleg, and Lant Pritchett. 1991. "European Trade Patterns After the Transition." Policy, Research and External Affairs Working Paper Series No. 748, August, World Bank.

Helliwell, John, 1998, How Much Do National Borders Matter? Brookings Institution: Washington DC.

Honkapohja, Seppo and Pentti Pikkarainen, 1992, "Country Characteristics and the Choice of Exchange Rate Regime: Are Mini-Skirts Followed by Maxis?" CEPR Discussion Paper No. 774, Dec. 
Hughes Hallett, Andrew, and Laura Piscitelli, 1999, "Will a Single Currency Induce Economic Convergence in Europe: A New Look at the Endogenous Optimal Currency Area Hypothesis," University of Strathclyde.

Imbs, Jean, 1999, "Co-Fluctuations," Centre for Economic Policy Research discussion paper no. 2267, October.

Imbs, Jean, 2003, “Trade, Finance, Specialization, and Synchronization,” IMF Working Paper no. 03/81, April.

Kalemli-Ozcan, Sebnem, Bent Sorensen, and Oved Yosha, 1999, "Risk-Sharing and Industrial Specialization: Regional and International Evidence," Centre for Economic Policy Research Discussion Paper No. 2295, November.

Kalemli-Ozcan, Sebnem, Bent Sorensen, and Oved Yosha, 2001, "Economic Integration, Industrial Specialization, and the Asymmetry of Macroeconomic Fluctuations," Journal of International Economics, 55, 107-137.

Keller, Wolfgang, 2001, “International Technology Diffusion,” NBER Working Paper No. 8573, October.

Kenen, Peter, 1969, "The Theory of Optimum Currency Areas: An Eclectic View," in R. Mundell and A.Swoboda, eds., Monetary Problems in the International Economy, Chicago: University of Chicago Press.

Kenen, Peter, and Ellen Meade, 2003, "EU Accession and the Euro: Together or Far Apart?" International Economics Policy Briefs No. PB03-09, October, Institute for International Economics, Washington, DC.

Kose, M.A., and K.-M. Yi, 2001, "International Trade and Business Cycles: Is Vertical Specialization the Missing Link," American Economic Review, May, 371-375.

Krugman, Paul, 1993, "Lessons of Massachusetts for EMU," in Francesco Giavazzi and Francisco Torres, eds., The Transition to Economic and Monetary Union in Europe, Cambridge University Press, New York, 241-261.

McCallum, John, 1995, "National Borders Matter: Canada-U.S. Regional Trade Patterns," American Economic Review 85, no.3, June, 615-623.

McKinnon, Ronald, 1963, “Optimum Currency Areas,” American Economic Review (September), 717-24.

Micco, Alejandro, Ernesto Stein, and Guillermo Ordoñez, 2003, "The Currency Union Effect on Trade: Early Evidence from the European Union," InterAmerican Development Bank, Washington DC , April 2002. Economic Policy no. 37, October,_2003, 315-343.

Micco, Alejandro, Ernesto Stein, and Guillermo Ordoñez, 2002b, "Should the UK join EMU?" InterAmerican Development Bank, Washington DC .

Mundell, Robert, 1961, "A Theory of Optimum Currency Areas", American Economic Review, November, 509-517.

Nitsch, Volker, 1991, "National Borders and International Trade: Evidence from the European Union," Bankgesellschaft Berlin, December.

The No Campaign, 2001, The Economic Case Against the Euro (New Europe: London).

Parsley, David, and Shang-Jin Wei, 2000, "Explaining the Border Effect: The Role of Exchange Rate Variability, Shipping Costs, and Geography," Journal of International Economics, forthcoming.

Parsley, David, and Shang-Jin Wei, 2001, "Limiting Currency Volatility to Stimulate Goods Market Integration: A Price Based Approach,” NBER Working Papper No. 8468, Sept. 
Quah, Danny, "Regional Convergence Clusters Across Europe," 1996, Centre for Economic Policy Research Discussion Paper No. 1286, London.

Redding, Stephen, and Anthony Venables, 2000, "Economic Geography and International Inequality," Centre for Economic Policy Research, London.

Rockoff, Hugh, "How Long Did It Take the United States to Become an Optimal Currency Area?" NBER working Paper no. H124.

Rogers, John, 2001, "Price Level Convergence, Relative Prices, and Inflation in Europe," Interantional Finance Discussion Papers No. 699, Federal Reserve Board, March.

Rogers, John, 2002, "Monetary Union, Price Level Convergence, and Inflation: How Close is Europe to the United States, Federal Reserve Board.

Rose, Andrew, "One Money, One Market: The Effect of Common Currencies on Trade," Economic Policy, 2000.

Rose, Andrew, "Currency Unions and Trade: The Effect is Large," Economic Policy (2001).

Rose, Andrew, and Eric van Wincoop, 2001, "National Money as a Barrier to Trade: The Real Case for Currency Union," American Economic Association Papers and Proceedings.

Takata, Kiyoshi, 2002, “Joining the Fold: The Question of UK Entry into EMU," Institute for International Policy Studies policy paper 284E, Feb.

Tavlas, George, 1992, "The 'New' Theory of Optimal Currency Areas," International Monetary Fund, Washington, DC.

Torres, A. and O Vela, 2003, "Trade, Integration and Synchronization Between the Business Cycles of Mexico and the United States," North American Journal of Economics and Finance, 14, no. 3, Dec., 319-342.

Weber, Axel, 1991, "EMU and Asymmetries and Adjustment Problems in the EMS - Some Empirical Evidence," European Economy, 1, 187-207.

Wei, Shang Jin, 1996, "How Reluctant are Nations in Global Integration?” NBER Working Paper No. 5531, April.

Winters, L.Alan, 1997, "European Integration and the Rest of the World," Review of International Economics. 